\title{
Antioxidant activity, acetylcholinesterase inhibitory potential and phytochemical analysis of Sarcocephalus latifolius Sm. bark used in traditional medicine in Sudan
}

\author{
Alsiddig Osama ${ }^{1 *}$, Sufyan Awadelkarim ${ }^{1,2}$ and Amna Ali ${ }^{2}$
}

\begin{abstract}
Background: Sarcocephalus latifolius is used as a traditional medicine for curing many diseases in Sudan. The main objective of the current study was to determine the antioxidant activity and acetylcholinesterase inhibition (AChEl) of S. latifolius, and to estimate its total phenolic and flavonoid contents.

Methods: Antioxidant activity of the tested plant extracts was carried out by determining their ability to scavenge the 2,2-diphenyl-1-picryl hydrazyl (DPPH) free radical. On the other hand, AChE inhibitory activity was determined spectrophotometrically using the Ellman's colorimetric method. The levels of total phenols and flavonoids were determined quantitatively using spectrophotometric methods. MTT assay was consumed to assess the cytotoxic effect of the most active fractions. These fractions were subjected to phytochemical analysis using GC-MS techniques to determine thier chemical composition.
\end{abstract}

Results: Hexane and chloroform fractions exhibited the highest antioxidant activity with $I C_{50}$ values of $(0.098 \pm 0.08$ and $0.099 \pm 0.029 \mathrm{mg} / \mathrm{ml}$ ) respectively. Standard propyl gallate had the lowest $I C_{50}$ value of $0.0414 \pm 0.11 \mathrm{mg} / \mathrm{ml}$. The ethanolic crude extract showed low AChEl activity with $40.2 \pm 0.10 \%$. High concentrations of phenolic and flavonoid contents were observed. GCMS revealed the presence of well-known antioxidants compounds e.g. Vitamin E and caffeic acid.

Conclusion: The ethanolic extract of bark of S. latifolius showed potent antioxidant effects and low AChEl activity, high phenolic and flavonoid contents and presence of pharmacologically active compounds. These findings explain its wide usages in traditional medicine.

Keywords: S. latifolius, Antioxidant, Acetylcholinesterase, Phenolics, Flavonoids, Gcms

\section{Background}

Due to its high reactivity, Oxygen is capable of becoming part of potentially damaging molecules called reactive oxygen species (ROS) [1]. Humans have evolved a highly sophisticated antioxidant protective system, both endogenous and exogenous in origin [2]. Whenever the balance between ROS production and antioxidant effect is disturbed, 'oxidative stress' results leading to various pathological conditions [3]. Many researchers have

\footnotetext{
*Correspondence: alsiddigosama@gmail.com

${ }^{1}$ Chemistry Department, Omdurman Islamic University, P.O. Box 382,

Omdurman, Sudan

Full list of author information is available at the end of the article
}

focused on antioxidant activity of phenolic compounds especially flavonoids and a positive correlation was observed [4-6]. ROS are playing a dangerous role in the pathogenesis of various diseases, including neurodegenerative disorders, cancer and artherosclerosis [7, 8]. Oxidative processes are the pathogens associated with the central nervous system in Alzheimer's disease (AD). The brain in particular is highly vulnerable to oxidative damage as it consumes about $20 \%$ of the body's total oxygen, with a high content of polyunsaturated fatty acids and lower levels of endogenous antioxidants $[9,10]$. The brain of patients suffering from $\mathrm{AD}$ is said to be under oxidative stress. [11, 12]. AD is the 
most common neurodegenerative disorder, characterized clinically by progressive memory deficits and impaired cognitive function [13]. It is a major public health concern due to the increasing number of sufferers, placing strains on caregivers as well as on financial resources [14]. A deficiency in levels of the neurotransmitter acetylcholine (ACh) has been observed in the brains of AD patients, and inhibition of acetylcholinesterase (AChE), the key enzyme which hydrolyses $\mathrm{ACh}$, is a major treatment option for $\mathrm{AD}$ [15]. Traditionally plants have been shown to be good options in the search for AChE inhibitors. Recently, several plants have been identified as containing AChEI activity [7]. In this respect, medicinal plants provide a rich source of biologically active constituents with multiple activities. Sarcocephalus latifolius Sm. (family: Rubiaceae), locally known as "Karmadoda", have many uses in traditional medicine including malaria, dysentery, fever, hypertension and health promotion (antioxidant) [16-18].

\section{Methods}

\section{Plant materials}

Bark samples of S. latifolius were collected from South Kordfan state in February 2015. Identified and authenticated by Prof. Hatel H. Alkamali, Faculty of Science and Technology, Omdurman Islamic University, and confirmed by plant taxonomists at the herbarium of Medicinal and Aromatic Plants Research Institute, National Center for Research. Khartoum, Sudan.

\section{Extraction}

The fresh samples were dried in shade for seven days, pulverized then used for extraction. Cold maceration methodology was carried out according to published method of Osama and Awdelkarim, 2015 [19].

\section{Fractionation}

The crude extract was fractionated using liquid- liquid extraction methodology, which were carried by dissolving the samples in dist. $\mathrm{H}_{2} \mathrm{O}$ then partitioned between n-hexane, chloroform, ethyl acetate and n-butanol respectively using separating funnel apparatus.

\section{Qualitative phytochemical evaluation}

Phytochemical screening was conducted to determine the presence of natural products in the fractions of selected plants using standard methods [20, 21].

\section{Determination of total phenolic content}

Total phenolic content was determined by Folin Ciocalteu method [22]. Calibration curve was constructed using gallic acid standards Fig. 1 and the total phenolic
Table 1 Preliminary screening of secondary metabolites in the fractions of S. latifolius

\begin{tabular}{|c|c|c|c|c|c|c|}
\hline \multirow{2}{*}{$\begin{array}{l}\text { Family of } \\
\text { compound }\end{array}$} & \multirow[t]{2}{*}{ Type of test } & \multicolumn{5}{|c|}{ interference } \\
\hline & & n-hexane & $\mathrm{CHCl}_{3}$ & EtOAc & $\mathrm{n}-\mathrm{BuOH}$ & $\overline{\mathrm{H}_{2} \mathrm{O}}$ \\
\hline Phenols & $\mathrm{FeCl}_{3}$ & $+\mathrm{V}$ & $+\mathrm{V}$ & $+\mathrm{V}$ & $+\mathrm{V}$ & $+\mathrm{V}$ \\
\hline Tannins & $\mathrm{FeCl}_{3}$ & $-V$ & $+\mathrm{V}$ & $+\mathrm{V}$ & $+\mathrm{V}$ & $+\mathrm{V}$ \\
\hline \multirow[t]{3}{*}{ Flavonoids } & $\mathrm{KOH}$ & $+\mathrm{V}$ & $+\mathrm{V}$ & $+\mathrm{V}$ & $+\mathrm{V}$ & $+\mathrm{V}$ \\
\hline & Alkaline & $+v$ & $+v$ & $+\mathrm{V}$ & $+v$ & $+v$ \\
\hline & Lead acetate & $+\mathrm{V}$ & $+\mathrm{V}$ & $+\mathrm{V}$ & $+\mathrm{V}$ & $+\mathrm{V}$ \\
\hline Quinones & $\mathrm{H}_{2} \mathrm{SO}_{4}$ & $-V$ & $+\mathrm{V}$ & $+\mathrm{V}$ & $+\mathrm{V}$ & $+\mathrm{V}$ \\
\hline \multirow[t]{2}{*}{ Alkaloids } & Dragendorff's & $+\mathrm{V}$ & $+\mathrm{V}$ & $+\mathrm{V}$ & $+\mathrm{V}$ & $+\mathrm{V}$ \\
\hline & Wagner's & $+\mathrm{V}$ & $+\mathrm{V}$ & $+\mathrm{V}$ & $+\mathrm{V}$ & $+\mathrm{V}$ \\
\hline Triterpenes & Salkowski & $+\mathrm{V}$ & $+\mathrm{V}$ & $+\mathrm{V}$ & $+\mathrm{V}$ & $+\mathrm{V}$ \\
\hline Diterpenes & Copper acetate & $-V$ & $-\mathrm{V}$ & $-V$ & $-\mathrm{V}$ & $-\mathrm{V}$ \\
\hline Steroids & Salkowski & $+\mathrm{V}$ & $+\mathrm{V}$ & $+\mathrm{V}$ & $+\mathrm{V}$ & $+\mathrm{V}$ \\
\hline Saponins & Forth & $-V$ & $+\mathrm{V}$ & $+\mathrm{V}$ & $-V$ & $+\mathrm{V}$ \\
\hline
\end{tabular}

+ve positive -ve negative

content was expressed as $\mathrm{mg}$ gallic acid equivalents (GAE)/g dry weight (DW).

\section{Determination of flavonoid content}

The flavonoid content was measured by the aluminium chloride colorimetric assay [23]. Calibration curve was plotted using quercetin standards and flavonoid content was expressed as mg quercetin equivalents $(\mathrm{QE}) / \mathrm{g} \mathrm{DW}$.

\section{GC-MS analysis}

GC-MS analysis was carried out using GCMS instrument (Model GCMS-QP2010 Ultra, Shimadzu Co., Japan) equipped with a capillary column Rtx-5 $(0.25 \mathrm{~m}$ film $\times$ $0.25 \mathrm{~mm}$ i.d. $\times 30 \mathrm{~m}$ length). The instrument was operated in electron impact mode at ionization voltage $(70 \mathrm{eV})$, injector temperature $\left(250{ }^{\circ} \mathrm{C}\right)$, and detector temperature $\left(280{ }^{\circ} \mathrm{C}\right)$. The carrier gas used was helium $(99.9 \%$ purity) at a flow rate of $1.2 \mathrm{~mL} / \mathrm{min}$ and about one $\mathrm{L}$ of the sample was injected. The oven temperature was initially programmed at $110^{\circ} \mathrm{C}(7 \mathrm{~min})$ to $200{ }^{\circ} \mathrm{C}$ at $10^{\circ} \mathrm{C} / \mathrm{min}$ and from 200 to $280{ }^{\circ} \mathrm{C}$ at $5{ }^{\circ} \mathrm{C} / \mathrm{min}$ withhold time 0 and

Table 2 Yield percentages, Total phenolic and flavonoid contents of ethanolic extract and solvent fractions of S. latifolius

\begin{tabular}{llll}
\hline Sample & $\begin{array}{l}\text { Extraction yield } \\
(w / w \% \text { of dry weight })\end{array}$ & $\begin{array}{l}\text { Phenolic content } \\
\text { (mg /g GAE) }\end{array}$ & $\begin{array}{l}\text { Total flavonoid } \\
\text { (mg/g QE) }\end{array}$ \\
\hline Crude & 47.33 & $78.21 \pm 2.4$ & $91.36 \pm 0.84$ \\
Hexane & 6.18 & $98.78 \pm 2.1$ & $81.01 \pm 0.012$ \\
$\mathrm{CHCl}_{3}$ & 1.64 & $71.49 \pm 0.5$ & $118.29 \pm 0.21$ \\
$\mathrm{EtOAC}$ & 3.09 & $86.12 \pm 0.7$ & $80.23 \pm 0.03$ \\
$\mathrm{BuOH}$ & 19.09 & $56.20 \pm 1.23$ & $94.32 \pm 0.71$ \\
$\mathrm{H}_{2} \mathrm{O}$ & 70.91 & $83.20 \pm 3.7$ & $40.22 \pm 0.28$ \\
\hline
\end{tabular}


Table 3 Antioxidant activity (\%RSA and $\mathrm{IC}_{50}$ ) of solvent fractions of S. latifolius

\begin{tabular}{lll}
\hline Sample & $\%$ RSA & $I_{50}(\mathrm{mg} / \mathrm{ml})$ \\
\hline Hexane & $76 \pm 0.02$ & $0.098 \pm 0.08$ \\
$\mathrm{CHCl}_{3}$ & $86 \pm 0.03$ & $0.099 \pm 0.029$ \\
$\mathrm{EtOAC}$ & $84 \pm 0.03$ & $0.148 \pm 0.33$ \\
$\mathrm{BuOH}$ & $83 \pm 0.02$ & $0.104 \pm 0.19$ \\
$\mathrm{H}_{2} \mathrm{O}$ & $79 \pm 0.10$ & $2.015 \pm 0.3$ \\
\hline
\end{tabular}

9 min respectively. The identification of compounds from the spectral data was based on the available mass spectral records (NIST and WILEY libraries).

\section{Antioxidant activity: 2,2-diphenyl-1-picrylhydrazyl (DPPH) radical scavenging assay}

The test samples were prepared in DMSO as $10 \times$ stocks from each test concentration (between 0 and $100 \mu \mathrm{g} / \mathrm{ml}$ ) and briefly sonicated when necessary in an ultrasonic water bath. Solvents fractions producing radical scavenging activities equal to or higher than $50 \%$ at $100 \mu \mathrm{g} / \mathrm{mL}$ in a preliminary screen were further tested and $\mathrm{IC}_{50}$ (concentration of the sample producing 50\% scavenging of DPPH radicals) determined using EZ-Fit Enzyme Kinetic Program. propyl gallate was tested in the assay as positive control. The assay method used in the present study was based on Shimada et al, 1992 [24] method. The samples stock solutions $(20 \mu \mathrm{L} /$ well $)$ were dispensed in triplicate onto 96-well plates. The assay was started with the addition of DPPH reagent $(300 \mu \mathrm{M}$ in ethanol, $180 \mu \mathrm{L} /$ well). Appropriate blanks were prepared using the solvent only in addition to the same amount of DPPH reagent to get rid of any inherent solvent activity. Negative controls were also run in parallel to correct for any non-DPPH absorbance by coloured extracts at the test wavelength. The plate was immediately shaken for $30 \mathrm{~s}$ and incubated in the dark for $30 \mathrm{~min}$ at room temperature. The remaining DPPH was measured in the microplate reader at $517 \mathrm{~nm}$. Percentage of radical scavenging activity (RSA) was calculated as following:

$$
\% \mathrm{RSA}=100-\{(\mathrm{Ac}-\mathrm{At}) / \mathrm{Ac}\} \times 100
$$

Where, At = Absorbance value of test compound; Ac $=$ Absorbance value of control.

\section{The multi-well plate $\mathrm{AChE}$ inhibition assay}

The AChE inhibitory activity was tested using 96 well micro-plate assay based on Ellmam et al., 1961 [25] method with minor modifications. Each extract $(10 \mu \mathrm{L}$ of $5 \mathrm{mg} / \mathrm{mL}$ in ethanol) was dispensed in triplicate onto 96 well microplate and mixed with $190 \mu \mathrm{L}$ of Ellman's mixture containing $20 \mu \mathrm{L}$ of enzyme, $140 \mu \mathrm{L}$ to phosphate buffer, $\mathrm{pH} \mathrm{8,} \mathrm{containing} 10 \mu \mathrm{L}$ of $0.5 \mathrm{mM}$ of 5, 5'dithio-bis-(2-nitrobenzoic acid) (DTNB, Sigma-Aldrich, Germany) and $20 \mu \mathrm{L}$ acetylthiocholine iodide (ATCI, Sigma-Aldrich, Germany). The control wells contained ethanol instead of the extract. The enzymatic activity was monitored at $412 \mathrm{~nm}$ every $30 \mathrm{~s}$ intervals for $3 \mathrm{~min}$ (linear reaction). The enzyme rate was calculated from the slope of the curve of absorbance vs time. As screening strategy, final concentration of $1000 \mu \mathrm{g} / \mathrm{mL}$ from each extract was examined and the average \% inhibition was calculated relative to the enzyme rate at the control wells according to the following equation:

$$
\% \text { Inhibition }=100-\{(\text { Ac-At }) / A c\} \times 100
$$

\section{MTT (3-(4, 5-dimethylthazol-2-yl)-2, 5-diphenyl tetrazonium} bromide) cytotoxicity assay

In the present investigation, Vero (normal, African green monkey kidney) cell line was used and cytotoxicity on these cells was assessed as described previously [26]. For each experiment, cultures were seeded from frozen stocks. Vero cells were maintained complete medium consisting of $10 \%$ fetal bovine serum and $90 \%$ minimal essential medium (MEM). The cells were incubated at $37{ }^{\circ} \mathrm{C}$ in a $5 \% \mathrm{CO}_{2}$ atmosphere and were in the logarithmic phase of growth at the time of the neutral red (NR) and tetrazolium (MTT) assays. Cells were harvested and seeded into 96-well tissue culture plates at a density of $1 \times 10^{4}$ cells per well of aliquots of medium $(200 \mu \mathrm{L})$.
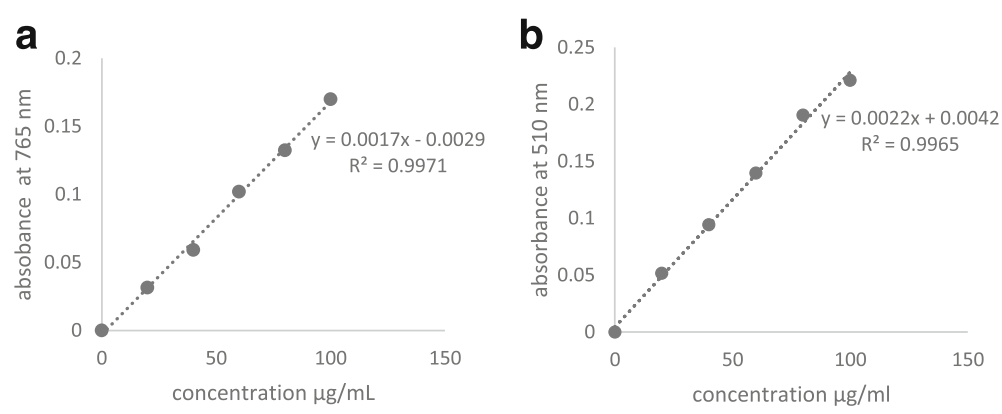

Fig. 1 Standard curves of (a) Gallic acid and (b) Quercetin shows the absorbance against concentration 

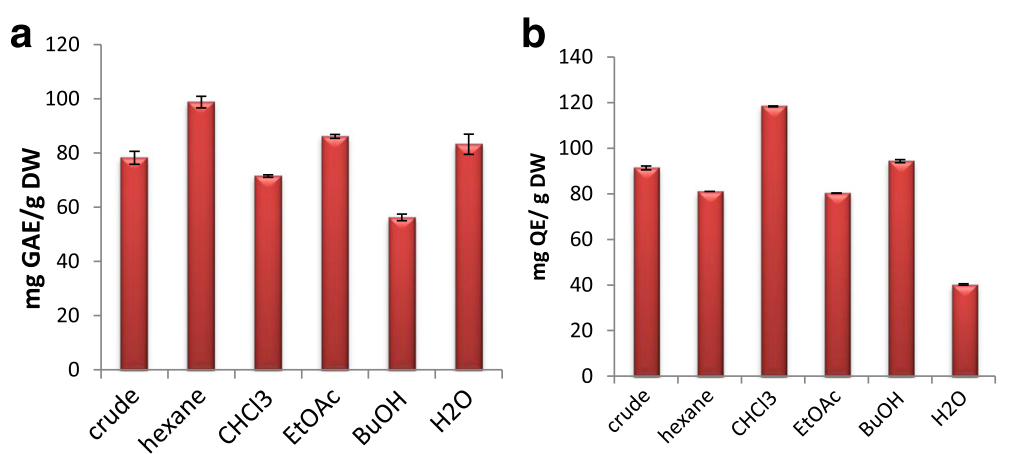

Fig. 2 Comparison charts of (a) Total phenolic content. b Total flavonoid content of ethanolic extract and solvent fractions of S. latifolius

The cells were allowed to adhere to the wells for $24 \mathrm{~h}$ at $37{ }^{\circ} \mathrm{C}$ in a humid atmosphere optimized with $5 \% \mathrm{CO}_{2}$ in air. The next day, the plant fractions were added at the desired final concentrations and incubated for $72 \mathrm{~h}$. All experiments were performed at least four times. Phosphate-buffered saline (PBS) was used as a negative. After the $72 \mathrm{~h}$ exposure period, the toxic endpoints were determined at $570 \mathrm{~nm}$. Viability was defined as the ratio (expressed as a percentage) of absorbance of treated cells to untreated cells that served as negative control.

\section{Statistical analysis}

All data were expressed as means \pm SD for three experiments. $P$ values $<0.05$ were considered statistically significant. Statistical analyses were performed using Excel software (Microsoft 2010).

\section{Results and discussion}

\section{Extraction yield and phytochemical screening}

The percentage yield of $S$. latifolius ethanolic extract was $47.33 \%$ of dry weight. The polar fractions (water and butanol) showed the highest percentage yield (Table 2), this could be attributed to the polar nature of the crude extract obtained with polar solvent (ethanol).
The results of preliminary investigation on the phytochemicals present in different solvent fractions are presented in Table 1. Different phytoconstituents such as phenolics, flavonoids, tannins, alkaloids, saponins, quinones, steroids, and terpenoids were detected in the tested fractions. The phytochemicals investigated in the present study are known to be beneficial in industrial and medicinal sciences [27]. Also, this preliminary knowledge can be looked at as a decipher in the search of a new source of economically valued chemical compounds [28, 29].

\section{Total phenolic and flavonoid contents}

Crude natural extracts and compounds purified from these extracts can serve as better herbal drug sources owing to their fewer side effects and nutritional value [30]. As presented in Table 2, the ethanolic crude extract of $S$. latifolius bark exhibited total phenolic content of $78.21 \pm 2.4 \mathrm{mg}$ GAE/g DW. Fig. 2 a similar study carried out using the methanolic leaf and root extracts of $S$. latifolius, has shown that the total phenolic content present was $(0.016 \pm 0.03$ and $0.036 \pm 0.05 \mathrm{mg}$ GAE/g DW) respectively, which is very low compared to the present study [31]. This

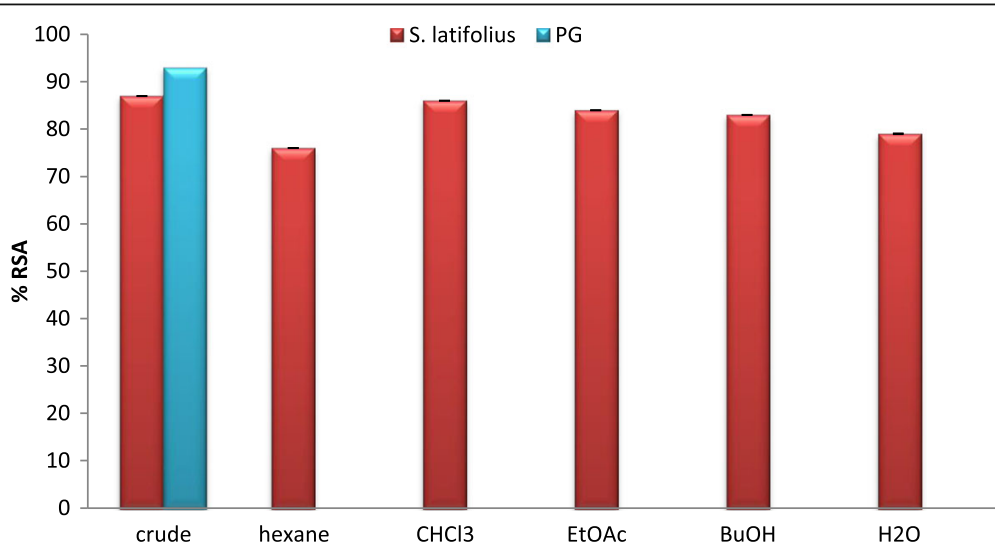

Fig. 3 Percentage of RSA of S. latifolius ehanolic extract and solvent fractions 


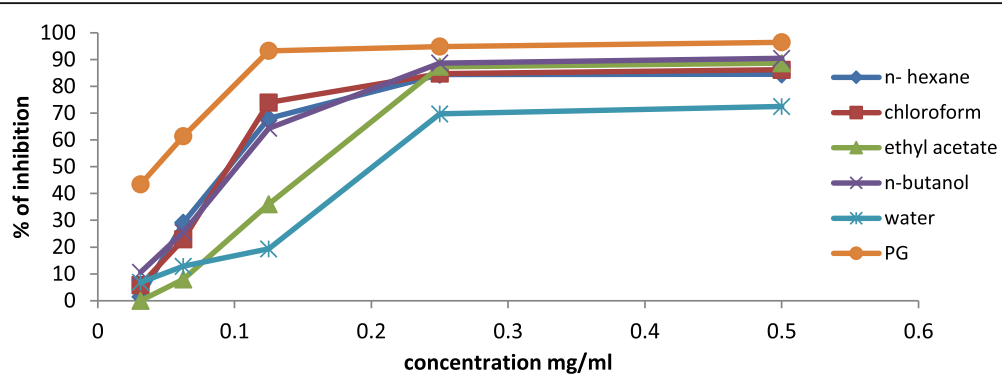

Fig. 4 Comparison Chart of Antioxidant potentials of S. latifolius fractions with the decrease of concentration (IC50 evaluation)

high variation could be due to many reasons includ- hexane fraction showed the highest phenolic content ing, the part of plant under study, which contains different chemical composition with different percentage, the method, solvent used for extraction, the origin of plant samples, and the environmental factors. The $(98.78 \pm 2.1 \mathrm{mg} \mathrm{GAE} / \mathrm{g} \mathrm{DW})$, this result indicates the presence of high lipid soluble phenolic compounds such as vitamin E, whose existence was confirmed by GCMS analysis.

Table 4 GC-MS spectral analysis of hexane fraction of S. latifolius bark

\begin{tabular}{|c|c|c|c|c|c|}
\hline Peak no. & R. Time & Area \% & Compunde name & Molecular Formula & Mass \\
\hline 1 & 13.736 & 1.68 & 5,5-Dimethyl-1,5-oxasilonan-9-one & $\mathrm{C}_{9} \mathrm{H}_{18} \mathrm{O}_{2} \mathrm{Si}$ & 186 \\
\hline 2 & 15.467 & 5.67 & Quinic acid & $\mathrm{C}_{7} \mathrm{H}_{12} \mathrm{O}_{6}$ & 192 \\
\hline 3 & 19.188 & 0.29 & Pentadecanoic acid, methyl ester & $\mathrm{C}_{16} \mathrm{H}_{32} \mathrm{O}_{2}$ & 256 \\
\hline 4 & 19.425 & 0.67 & Ethyl (2E)-3-(4-hydroxy-3-methoxyphenyl)-2-propenoate & $\mathrm{C}_{12} \mathrm{H}_{14} \mathrm{O}_{4}$ & 222 \\
\hline 5 & 19.805 & 6.89 & Pentadecanoic acid & $\mathrm{C}_{15} \mathrm{H}_{30} \mathrm{O}_{2}$ & 242 \\
\hline 6 & 20.147 & 2.20 & Palmitic acid ethyl ester & $\mathrm{C}_{18} \mathrm{H}_{36} \mathrm{O}_{2}$ & 284 \\
\hline 7 & 20.761 & 0.53 & 2-Cyclopropylideneadamantane & $\mathrm{C}_{13} \mathrm{H}_{18}$ & 174 \\
\hline 8 & 22.455 & 16.49 & Oleic Acid & $\mathrm{C}_{18} \mathrm{H}_{34} \mathrm{O}_{2}$ & 282 \\
\hline 9 & 22.694 & 3.23 & Methyl linoleate & $\mathrm{C}_{19} \mathrm{H}_{34} \mathrm{O}_{2}$ & 294 \\
\hline 10 & 22.765 & 1.64 & Ethyl octadec-9-enoate & $\mathrm{C}_{20} \mathrm{H}_{38} \mathrm{O}_{2}$ & 310 \\
\hline 11 & 22.814 & 0.48 & Linolenic acid methyl ester & $\mathrm{C}_{19} \mathrm{H}_{32} \mathrm{O}_{2}$ & 292 \\
\hline 12 & 23.122 & 3.91 & Heptadecanoic acid, ethyl ester & $\mathrm{C}_{19} \mathrm{H}_{38} \mathrm{O}_{2}$ & 298 \\
\hline 13 & 25.920 & 14.21 & Oelic acid amide & $\mathrm{C}_{18} \mathrm{H}_{35} \mathrm{~N} \mathrm{O}$ & 281 \\
\hline 14 & 25.994 & 0.23 & Oelic acid amide & $\mathrm{C}_{18} \mathrm{H}_{35} \mathrm{NO}$ & 281 \\
\hline 15 & 26.187 & 0.44 & Palmitic acid ethyl ester & $\mathrm{C}_{18} \mathrm{H}_{36} \mathrm{O}_{2}$ & 284 \\
\hline 16 & 26.265 & 0.60 & Stearic acid amide & $\mathrm{C}_{18} \mathrm{H}_{37} \mathrm{NO}$ & 283 \\
\hline 17 & 26.509 & 0.43 & 2-Pentyl-2-nonenal & $\mathrm{C}_{14} \mathrm{H}_{26} \mathrm{O}$ & 210 \\
\hline 18 & 26.761 & 0.43 & Oxirane, hexadecyl- & $\mathrm{C}_{18} \mathrm{H}_{36} \mathrm{O}$ & 268 \\
\hline 19 & 28.299 & 0.48 & Octadecanal & $\mathrm{C}_{18} \mathrm{H}_{36} \mathrm{O}$ & 268 \\
\hline 20 & 28.665 & 9.23 & Phthalic acid, mono-(2-ethylhexyl) ester & $\mathrm{C}_{16} \mathrm{H}_{22} \mathrm{O}_{4}$ & 278 \\
\hline 21 & 29.192 & 0.97 & Ethyl palmitate & $\mathrm{C}_{18} \mathrm{H}_{36} \mathrm{O}_{2}$ & 284 \\
\hline 22 & 29.881 & 19.50 & Cinchol & $\mathrm{C}_{29} \mathrm{H}_{50} \mathrm{O}$ & 414 \\
\hline 23 & 32.086 & 0.57 & Ethyl docosanoate & $\mathrm{C}_{24} \mathrm{H}_{48} \mathrm{O}_{2}$ & 368 \\
\hline 24 & 32.642 & 1.64 & Spinacene & $\mathrm{C}_{30} \mathrm{H}_{50}$ & 410 \\
\hline 25 & 33.176 & 0.59 & 3-[(Trimethylsilyl)oxy]lanosta-8,24-diene & $\mathrm{C}_{33} \mathrm{H}_{58} \mathrm{OSi}$ & 498 \\
\hline 26 & 33.343 & 1.44 & Lupenyl acetate & $\mathrm{C}_{32} \mathrm{H}_{52} \mathrm{O}_{2}$ & 468 \\
\hline 27 & 35.907 & 3.46 & Stigmast-4-en-3-one & $\mathrm{C}_{29} \mathrm{H}_{48} \mathrm{O}$ & 412 \\
\hline 28 & 38.248 & 1.09 & Cholesteryl bromide & $\mathrm{C}_{27} \mathrm{H}_{45} \mathrm{Br}$ & 448 \\
\hline 29 & 38.974 & 1.01 & Vitamin $\mathrm{E}$ & $\mathrm{C}_{29} \mathrm{H}_{50} \mathrm{O}_{2}$ & 430 \\
\hline
\end{tabular}


Successful determination of biologically active compounds from plant material is largely dependent on the type of solvent used in the extraction procedure. Higher concentrations of more bioactive flavonoid compounds were detected with $80 \%$ ethanol [32]. Therefore, ethanol was chosen for extraction. Plant phenolic compounds especially flavonoids are currently receiving greater interest due to their antioxidants potential [27, 33]. Aluminium chloride colorimetric assay yielded total flavonoid content of $(91.36 \pm 0.84 \mathrm{mg} \mathrm{QE} / \mathrm{g} \mathrm{DW})$ for the crude extract. Highest flavonoid contents were observed in chloroform fraction (118.29 $\pm 0.21 \mathrm{mg} \mathrm{QE} / \mathrm{g} \mathrm{DW})$, which indicate the high amount of less polar flavonoids (aglycones) such as isoflavones, flavanones, highly methoxylated flavones, and flavonols [34]. These results could give a clue interpreting the observed high bioactivities of this plant.

\section{Antioxidant and AChE inhibitory activities}

Recently, interest has increased in naturally occurring antioxidants that can be used to protect human beings from oxidative stress damages $[35,36]$. In the current study, the ethanolic crude extract exhibited high antioxidant activity with $87 \pm 0.03 \%$. The order of the activity $\left(\mathrm{IC}_{50} \mathrm{mg} / \mathrm{ml}\right)$ was as follow: hexane $(0.098 \pm 0.08)>$ chloroform $(0.099 \pm 0.029)>$ butanol $(0.104 \pm 0.19)>$ ethyl acetate $(0.148 \pm 0.33)$ and eventually water fraction $(2.015 \pm 0.3)$, Table 3 and

Table 5 GC-MS spectral analysis of chloroform fraction of S. latifolius bark

\begin{tabular}{|c|c|c|c|c|c|}
\hline Number & R. Time & Area \% & Compound name & Molecular Formula & Mass \\
\hline 1 & 13.735 & 2.97 & 5,5-Dimethyl-1-oxa-5-silacyclononanone-9 & $\mathrm{C}_{9} \mathrm{H}_{18} \mathrm{O}_{2} \mathrm{Si}$ & 186 \\
\hline 2 & 14.635 & 0.29 & 9-Eicosene, (E)- & $\mathrm{C}_{20} \mathrm{H}_{40}$ & 280 \\
\hline 3 & 15.989 & 1.99 & 2H-Pyran-2-one, 5-ethylidenetetrahydro-4-(2-hydroxyethyl)- & $\mathrm{C}_{9} \mathrm{H}_{14} \mathrm{O}_{3}$ & 170 \\
\hline 4 & 17.029 & 0.85 & 4-((1E)-3-Hydroxy-1-propenyl)-2-methoxyphenol & $\mathrm{C}_{10} \mathrm{H}_{12} \mathrm{O}_{3}$ & 180 \\
\hline 5 & 17.334 & 0.35 & 1-Heptadecene & $\mathrm{C}_{17} \mathrm{H}_{34}$ & 238 \\
\hline 6 & 18.302 & 0.84 & p-Hydroxycinnamic acid, ethyl ester & $\mathrm{C}_{11} \mathrm{H}_{12} \mathrm{O}_{3}$ & 192 \\
\hline 7 & 19.187 & 0.35 & 9-Octadecenoic acid, 12-(acetyloxy)-, methyl ester, [R-(Z)]- & $\mathrm{C}_{21} \mathrm{H}_{38} \mathrm{O}_{4}$ & 354 \\
\hline 8 & 19.361 & 0.18 & 7,9-Di-tert-butyl-1-oxaspiro(4,5)deca-6,9-diene-2,8-dione & $\mathrm{C}_{17} \mathrm{H}_{24} \mathrm{O}_{3}$ & 276 \\
\hline 9 & 19.422 & 0.15 & alpha.-D-Xylofuranose, 1,2-0-isopropylidene-5-(t-butyldimethylsilyl)- & $\mathrm{C}_{14} \mathrm{H}_{28} \mathrm{O}_{5} \mathrm{Si}$ & 304 \\
\hline 10 & 19.800 & 5.89 & Pentadecanoic acid & $\mathrm{C}_{15} \mathrm{H}_{30} \mathrm{O}_{2}$ & 242 \\
\hline 11 & 20.115 & 0.30 & 9-Tricosene, (Z)- & $\mathrm{C}_{23} \mathrm{H}_{46}$ & 322 \\
\hline 12 & 20.360 & 7.84 & 2H-1-Benzopyran-2-one, 7-hydroxy-6-methoxy- & $\mathrm{C}_{10} \mathrm{H}_{8} \mathrm{O}_{4}$ & 192 \\
\hline 13 & 20.761 & 0.62 & Bicylo[4.1.0]heptane, 7-bicyclo[4.1.0]hept-7-ylidene- & $\mathrm{C}_{14} \mathrm{H}_{20}$ & 188 \\
\hline 14 & 21.139 & 0.22 & Trimethylsilyl 3-methoxy-4-(trimethylsilyloxy)cinnamate & $\mathrm{C}_{16} \mathrm{H}_{26} \mathrm{O}_{4} \mathrm{Si}_{2}$ & 338 \\
\hline 15 & 21.769 & 0.31 & 9-Octadecenoic acid (Z)-, methyl ester & $\mathrm{C}_{19} \mathrm{H}_{36} \mathrm{O}_{2}$ & 296 \\
\hline 16 & 21.996 & 25.46 & 2-Propenoic acid, 3-(3,4-dihydroxyphenyl)- & $\mathrm{C}_{9} \mathrm{H}_{8} \mathrm{O}_{4}$ & 180 \\
\hline 17 & 22.450 & 9.78 & Oleic Acid & $\mathrm{C}_{18} \mathrm{H}_{34} \mathrm{O}_{2}$ & 282 \\
\hline 18 & 22.762 & 3.28 & Octadecanoic acid & $\mathrm{C}_{18} \mathrm{H}_{36} \mathrm{O}_{2}$ & 284 \\
\hline 19 & 23.104 & 1.19 & 1-Hexadecene & $\mathrm{C}_{16} \mathrm{H}_{32}$ & 224 \\
\hline 20 & 23.740 & 0.61 & 9,12-Octadecadienoic acid (Z,Z)- & $\mathrm{C}_{18} \mathrm{H}_{32} \mathrm{O}_{2}$ & 280 \\
\hline 21 & 25.816 & 0.39 & O O'-BIPHENOL, 4,4',6,6'-TETRA-T-BUTYL- & $\mathrm{C}_{28} \mathrm{H}_{42} \mathrm{O}_{2}$ & 410 \\
\hline 22 & 25.909 & 1.08 & 9-Octadecenamide, (Z)- & $\mathrm{C}_{18} \mathrm{H}_{35} \mathrm{NO}$ & 281 \\
\hline 23 & 26.155 & 0.93 & 1-Nonadecene & $\mathrm{C}_{19} \mathrm{H}_{38}$ & 266 \\
\hline 24 & 28.301 & 0.19 & Oxirane, heptadecyl- & $\mathrm{C}_{19} \mathrm{H}_{38} \mathrm{O}$ & 282 \\
\hline 25 & 28.662 & 1.17 & 1,2-Benzenedicarboxylic acid, mono(2-ethylhexyl) ester & $\mathrm{C}_{16} \mathrm{H}_{22} \mathrm{O}_{4}$ & 278 \\
\hline 26 & 29.163 & 1.28 & 1-Nonadecene & $\mathrm{C}_{19} \mathrm{H}_{38}$ & 266 \\
\hline 27 & 29.732 & 1.15 & gamma.-Sitosterol & $\mathrm{C}_{29} \mathrm{H}_{50} \mathrm{O}$ & 414 \\
\hline 28 & 32.053 & 1.83 & 1-Triacontanol & $\mathrm{C}_{24} \mathrm{H}_{50} \mathrm{O}$ & 354 \\
\hline 29 & 35.350 & 1.02 & 17-Pentatriacontene & $\mathrm{C}_{35} \mathrm{H}_{70}$ & 490 \\
\hline 30 & 35.848 & 5.09 & Methyl commate C & $\mathrm{C}_{31} \mathrm{H}_{50} \mathrm{O}_{4}$ & 486 \\
\hline 31 & 38.123 & 22.40 & Lup-20 (29)-en-3-ol, acetate, (3.beta.)- & $\mathrm{C}_{32} \mathrm{H}_{52} \mathrm{O}_{2}$ & 468 \\
\hline
\end{tabular}


Figs. 3, and 4 illustrate these results. The activity of hexane and chloroform fractions $(0.098 \pm 0.08$ and $0.099 \pm 0.029 \mathrm{mg} / \mathrm{ml}$ ) respectively, is comparable values to the standard antioxidant PG $(0.0414 \pm 0.11 \mathrm{mg} / \mathrm{ml})$; they also showed high amount of phenolic and flavonoid contents, it's possible that could be the reason of this high antioxidant potential.

Inhibition of AChE has been considered as a promising strategy for the treatment of neurological disorders such as Alzheimer's disease, senile dementia, ataxia and myasthenia gravis, in which a deficit in cholinergic neurotransmission is involved [37, 38]. The side effects of anti-AChE drugs such as toxicity, tolerability, and loss of efficiency stimulates the researchers to screen alternative natural anti-AD drugs for medication switch [39]. Ethanolic extract displayed low AChE inhibitory activity with (40.2 \pm 0.10$)$. GCMS analysis of chloroform fraction indicates the presence of caffeic acid which has been reported to be a potent inhibitor of both AChE and BChE [40]. It is possible that the solvent used for extraction was not able to isolate the active ingredients with a proper amount.

\section{GCMS analysis}

Due to their superior antioxidant activities hexane and chloroform fractions were analyzed with GC-MS, to identify their chemical composition which may be responsible of the measured activities. The GC-MS analysis lead to the identification of a number of compounds. These compounds were identified through mass spectrometry attached with GC. Interpretation of mass spectrum was conducted using the database of $\mathrm{Na}$ tional Institute Standard and Technology (NIST). The name, molecular weight and structure of the components of the test materials were ascertained, illustrated in Tables 4, and 5 and Figs. 5, and 6.

GC-MS spectrum of the hexane and chloroform fractions revealed the presence of 29 and 31 compounds respectively. Two phenolic compounds (Ethyl (2E)-3-(4-hydroxy-3-methoxyphenyl)-2-propenoate and Vitamin E) were observed in hexane fraction. Fat soluble vitamin $\mathrm{E}$ is one of the most active natural antioxidants, it is the most effective chain-breaking antioxidant within the cell membrane where it protects membrane fatty acids from lipid peroxidation. The supplemental intakes of this powerful antioxidant have been documented to be useful against cancer [41]. Vitamin $\mathrm{E}$ also acts in the prevention of free radical formation.

chloroform fraction declared the presence of five phenolic substances (4-((1E)-3-Hydroxy-1-propenyl)-2methoxyphenol; p-Hydroxycinnamic acid, ethyl ester; 2H-1-Benzopyran-2-one, 7-hydroxy-6-methoxy; Caffeic acid, O O'-biphenol, 4,4,6,6'-tetra-T-butyl) these phenolic compounds are known antioxidants, therefore the antioxidant potentials of this plant could be justified. However, further studies on the isolation, characterization, and biological evaluation of these identified compounds are necessary to confirm their potential benefits.

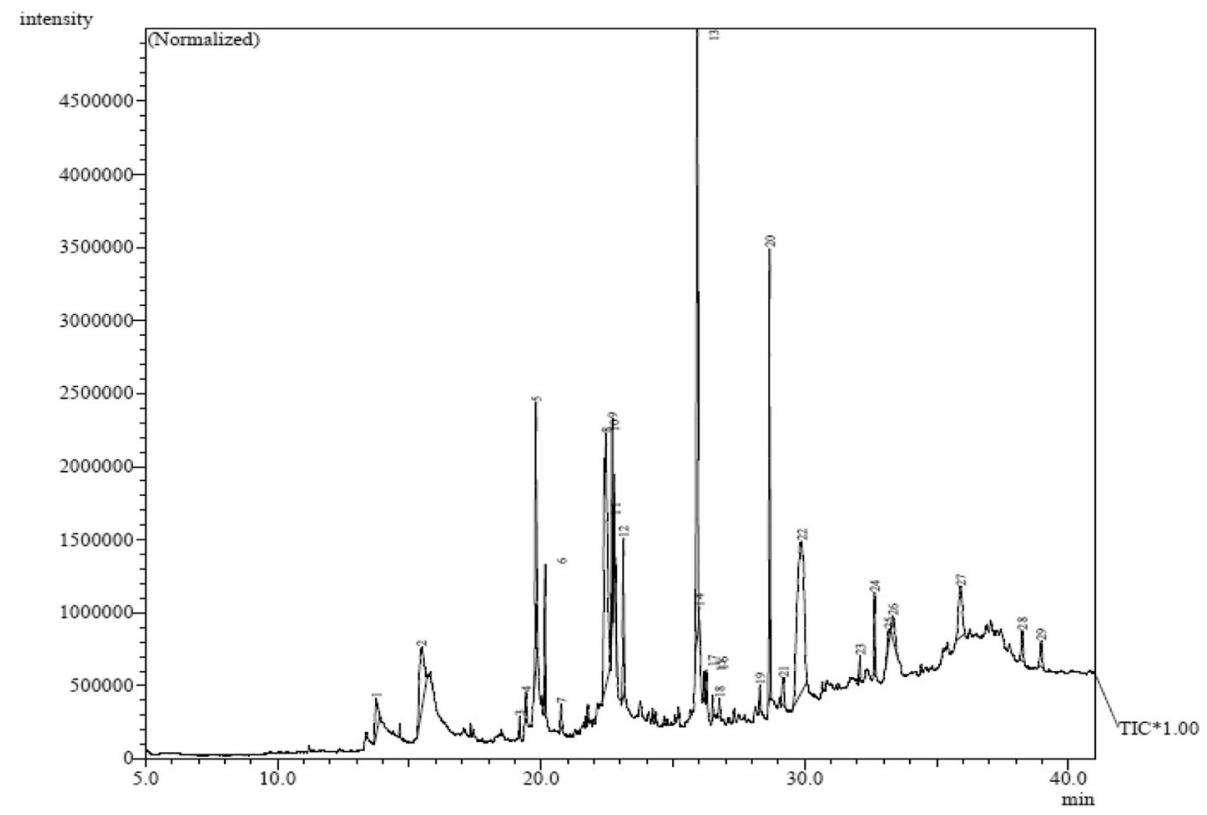

Fig. 5 GC-MS chromatogram for hexane fraction of S. latifolius bark 


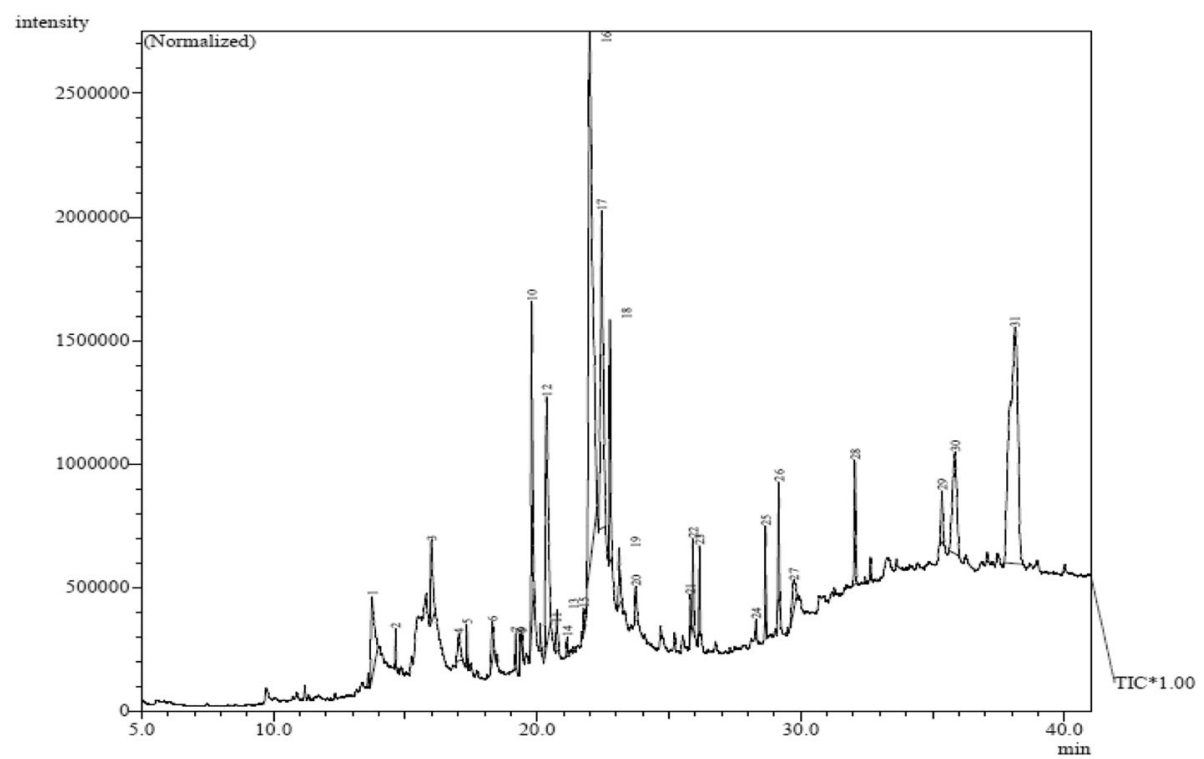

Fig. 6 GC-MS chromatogram for chloroform fraction of S. latifolius bark

\section{Cytotoxicity study}

MTT assay reveled that, all tested fractions have no toxic effects on Vero cells with $\mathrm{IC}_{50}$ more than $200 \mu \mathrm{g} / \mathrm{ml}$, these results are shown in (Table 6).

The MTT assay is a test of metabolic competence based upon assessment of mitochondrial performance relying on the conversion of yellow MTT to the purple formazan derivative by mitochondrial succinate dehydrogenase in viable cells [42]. Increasing concentrations of the tested fractions did not affect mitochondrial respiration as measured by the MTT cytotoxicity assay. However, the results of this assay measuring cell integrity showed that these solvent fractions are not toxic over this concentration range tested.

\section{Conclusion}

S. latifolius is a Sudanese medicinal plants commonly used as herbal medicine for several purposes. In the present study, the selected plant was investigated in vitro for AChEI and antioxidant properties. In addition, the total phenolic and flavonoids contents were measured.

Table 6 The cytotoxic effect (expressed as \% inhibition and IC50 values) of hexane and chloroform fractions of S. latifolius tested at 125, 250 and $500 \mu \mathrm{g} / \mathrm{ml}$ against Vero cells

\begin{tabular}{|c|c|c|c|c|c|}
\hline \multirow{3}{*}{$\begin{array}{l}\text { Code of } \\
\text { extract }\end{array}$} & \multicolumn{3}{|c|}{ Concentration $(\mu \mathrm{g} / \mathrm{ml})$} & \multirow{3}{*}{$\begin{array}{l}\mathrm{I} C_{50} \\
(\mu \mathrm{g} / \mathrm{ml})\end{array}$} & \multirow[t]{3}{*}{$\mathrm{IC}_{50}$} \\
\hline & \multicolumn{3}{|c|}{ Inhibition $\% \pm$ SD } & & \\
\hline & 500 & 250 & 125 & & \\
\hline Hexane & $55.3 \pm 0.04$ & $50.4 \pm 0.02$ & $40.9 \pm 0.03$ & 277.8 & $>100$ \\
\hline Chloroform & $67.6 \pm 0.08$ & $55.0 \pm 0.01$ & $35.9 \pm 0.05$ & 224.9 & $>100$ \\
\hline Control & $95.3 \pm 0.00$ & & & & $<30$ \\
\hline
\end{tabular}

$\mathrm{IC}_{50}<30 \mu \mathrm{g} / \mathrm{ml}$ : High toxic. Control = triton was used as positive control at $0.2 \mu \mathrm{g} / \mathrm{ml}$. the maximum concentration used was $500 \mu \mathrm{g} / \mathrm{ml}$
GC-MS analysis of S. latifolius (hexane and chloroform) fractions reveled the presence of well known antioxidant compound such as Vitamin E and Caffeic acid. According to these findings it could be suggested that S. latifolius (hexane and chloroform) fractions might be potent and safe antioxidant materials in medicine or food industry.

\section{Abbreviations}

Abs: Absorbance; Ac: Absorbance value of Control; Ach: Acetylcholine; AChE: Acetylcholinesterase; AChEl: Acetylcholinesterase Inhibitory; AD: Alzheimer's Disease; At: Absorbance value of Test compound; BuOH: Butanol; DMSO: Dimethyl sulfoxide; DPPH: 2,2-diphenyl-1-picryl hydrazyl; DTNB: 5,5'-Dithiobs (2-nitro benzoic acid); El: Electron lonization; EtOAc: Ethyl Acetate; FBS: Fetal Bovine Serum; GAE: Gallic Acid Equivalent; GC: Gas Chromatography; GC-MS: Gas Chromatography- Mass Spectrometer; MEM: Minimal Essential Medium; MTT: Microculture tetrazolium; NIST: National Institute of Standards and Technology; PG: Propyl Gallate; QE: Quercetin Equivalent; RSA: Radical Scavenging Activity

\section{Acknowledgements}

We would like to express our deep gratitude to Prof. Hatel H. Alkamali, Dean of Faculty of Science and Technology, Omdurman Islamic University, and Prof. Asaad Khalid, Medical Biochemistry Research Department, Medicinal and Aromatic Plants Research Institute, National Center for Research, Khartoum, Sudan, for their advices.

Funding

These analyses were done with self-funding.

Availability of data and materials

All data and materials used in this research are available from the corresponding author on reasonable request.

\section{Authors' contributions}

AO Conduct the extraction, fractionation, phytochemical screening, total phenolic and total flavonoid content as well as the GCMS analysis and wrote the first draft. SA Supervised all the experimental work and data interpretation and also corrects the first draft. AA Conduct the antioxidant and anti- AChE inhibitory activities and the cytotoxicity experiment. All authors read and approved the final manuscript. 


\section{Competing interests}

The authors declare that they have no competing interests.

\section{Ethics approval and consent to participate}

Not applicable.

\section{Declaration}

The experimental work described in this article was conducted in the Chemical Laboratories Complex, Department of Chemistry, Faculty of Sciences and Technology, Omdurman Islamic University, and Research Lab, Medical Biochemistry Department, Medicinal and Aromatic Plants Research Institute, National Center for Research. Khartoum, Sudan, from December 2014 to September 2015. These studies are the result of our own investigations, except where the work of others is acknowledged and have not been submitted in any other form to another journal.

\section{Publisher's Note}

Springer Nature remains neutral with regard to jurisdictional claims in published maps and institutional affiliations.

\section{Author details}

'Chemistry Department, Omdurman Islamic University, P.O. Box 382, Omdurman, Sudan. ${ }^{2}$ Medical Biochemistry Research Unit, Medicinal and Aromatic Plants Research Institute, National Centre for Research, P.O. Box 2404, Khartoum, Sudan.

Received: 16 October 2016 Accepted: 8 May 2017

Published online: 18 May 2017

\section{References}

1. Bandyopudya U. ROS: oxidative damage and pathogenesis. Curr Sci. 1999; 77:658-66.

2. Percival M. Antioxidants. Clin Nutr Insights. 1998;31:01-4

3. Chitra KP, Pillai KS. Antioxidants in health. Ind J Physiol Pharmacol. 2002; 46(1):01-5.

4. Cai Y, Luo Q, Sun M, Corke H. Antioxidant activity and phenolic compounds of 112 traditional Chinese medicinal plants associated with anticancer. Life Sci. 2004;74:2175-84

5. Djeridane A, Yousfi M, Nadjemi B, Boutassouna D, Stocher P, Vidal N. Antioxidant activity of some Algerian medicinal plants extracts containing phenolic compounds. Food Chem. 2006;97:654-60.

6. Sroka Z, Cisowski W. Hydrogen peroxide scavenging, antioxidant and antiradical activity of some phenolic acids. Food Chem Toxicol. 2002;41:753-8.

7. Winrow VR, Winyard PG, Morris CJ, Blake DR. Free radicals in inflammation: second messengers and mediators of tissue destruction. Brit Med Bull. 1993; 49(3):506-22.

8. Confortia F, Sosa S, Marrelli M, Menichini F, Statti G, Uzunov D. In vivo antiinflammatory and in vitro antioxidant activities of Mediterranean dietary plants. J Ethnopharmacol. 2007;116(1):144-51.

9. Halliwell B, Gutteridge JMC. Oxygen radicals and the nervous system. Trends Neuro Sc. 1985:8:22-6.

10. Shulman RG, Rothman DL, Behar KL, Hyder F. Energetic basis of brain activity: implications for neuroimaging. Trends Neurosci. 2004;27:489-95.

11. Emilien G, Beyreuther $\mathrm{K}$, Master CL, Maloteaux JM. Prospects for pharmacological intervention in Alzheimer's disease. Arch Neurol. 2000; 57(4):454-9

12. Tabet N. Acetylcholinesterase inhibitors for Alzheimer's disease: antiinflammatories in acetylcholine clothing. Age Ageing. 2006;35(4):336-8.

13. Mattson MP. Pathways towards and away from Alzheimer's disease. Nature. 2004:430:631-9

14. Houghton PJ, Howes MJ. Natural products and derivatives affecting neurotransmission relevant to Alzheimer's and Parkinson's disease. Neurosignals. 2005;14:6-22.

15. Şenol FS, Orhan I, Yilmaz G, Çiçek M, Şener B. Acetylcholinesterase, butyrylcholinesterase, and tyrosinase inhibition studies and antioxidant activities of 33 Scutellaria L. taxa from Turkey. Food Chem Toxicol. 2010;48: $781-8$.

16. Amos S, Abba J, Chindo B, Edmond I, Binda L, Adzu B, Buhari S, Odutola AA, Wambebe C, Gamaniel K. Neuropharmacological effects of the aqueous extract of Nauclea latifolia root back in rats and mice. J Ethnopharmacol. 2005;97(1):53-7.
17. Ngo Bum E, Taiwe GS, Motto FC, Ngoupaye GT, Nkantchoua GC, Pelanken MM, Rakotonirina SV, Rakotonirina A. Anticonvulsant, nxiolytic and sedative properties of the roots of Nauclea latifolia smith in mice. Epilepsy Behav. 2009;15(4):434-40

18. Abbah J, Amos S, Chindoc B, Ngazalc I, Vongtaue HO, Adzuc B, Faridad T, Odutolad AA, Wambebec C, Gamaniel KS. Pharmacological evidence favouring the use of Nauclea latifolia in malaria ethnopharmacy: effects against nociception, inflammation, and pyrexia in rats and mice. J Ethnopharmacol. 2010;127:85-90.

19. Osama A, Awdelkarim S. Phytochemical screening of Ficus sycomorus L. bark and Cleome gynandra L. aerial parts. J. Pharmacog. and. Phytochemistry. 2015;4(4):24-7.

20. Trease GE and Evans MD. A text book of Pharmacognosy. 13th ed. London: Bailliere Tindall; 1989.144-48.

21. Odebiyi O, Sofowora EA. Phytochemical screening of Nigerian medicinal plants. L Coydia. 1978;41:41-234.

22. Wolfe K, Wu X, Liu RH. Antioxidant activity of apple peels. J Agric Food Chem. 2003;51(3):609-14

23. Kim DO, Chun OK, Kim YJ, Moon HY, Lee CY. Quantification of polyphenolics and their antioxidant capacity in fresh plums. J Agric Food Chem. 2003;516:509-6515.

24. Shimada K, Fujikawa K, Yahara K, Nakamura T. Antioxidative properties of xanthan on the antioxidation of soybean oil in cyclodextrin emulsion. Agric Food Chem. 1992;40:945-8.

25. Ellman G, Diane C, Valentino A, Robert M. Biochemical pharmacolog. Pergamon P press Ltd. 1961;7:88-95.

26. Patel S, Gheewala N, Suthar A, Saha A. In- vitro cytotoxicity activity of Solanum Nigerian extract aginst Hela cell line and Vero cell line. In J pharm Pharmac Sci. 2009;1(1):38-46.

27. Rauha JP, Remes S, Herinonen W, Hopia M, Kgjala T, Pitinlaja K, Vaorela $H$, Vaorela P. Antimicrobial effects of finished plant extract containing flavanoids and other phenolic compounds. Int J Food Microbiol. 2000; $56: 3-12$.

28. Gezahegn Z, Akhtar MS, Woyessa D. And TarikuY. Antibacterial potential of Thevetia peruviana leaf extracts against food associated bacterial pathogens. J Coastal Life Med. 2015:3(2):150-7.

29. Mohanty SK. MalappaK, Godavarthi a, Subbanarasiman B and Maniyam a. Evaluation of antioxidant, in vitro cytotoxicity of micropropagated and naturally grown plants of Leptadenia reticulata (Retz.) Wight \& Arn.-an endangered medicinal plant. Asian Pac J Trop Med. 2014;7(1):S267-71.

30. Saetung A, Itharat A, Dechsukum C, Wattanapiro-msakul C, Keaprodub N, Ratansuwa P. Cytotoxic activity of Thai medicinal plants for cancer treatment. Sci Technol. 2005;27(2):469-78.

31. Dhalwal K, Shinde VM, Namdeo AG. Antioxidant profile and HPTLC densitometric analysis of umbelliferone and psoralen in Aegle marmelos. Pharm Biol. 2008;46:266-72.

32. Bimakr M. Comparison of different extraction methods for the extraction of major bioactive flavonoid compounds from spearmint (Mentha spicata L.) leaves. Food Bioprod Process. 2010;89(1):1-6.

33. Oise IE, Adesina AB, Oluwasegun AA. Comparative phytochemical, cytotoxic and growth inhibitory effects of the leaf and root barks of Sarcocephalus Latifolius (J.E. Smith) E.A. Bruce (Rubiaceae). Inter J Biosci. 2014;4(4):162-9.

34. Waksmundzka-Hajnos M, Sherma J, Kowalska T. Thin Layer Chromatography in Phytochemistry. CRC Press is an imprint of the Taylor \& Francis Group. 2008:99:334-36.

35. Aruoma OI, Halliwell B, Aeschbach R, Löligers J. Antioxidant and prooxidant properties of active rosemary constituents: Carnosol and carnosic acid. Xenobiotica. 1992:22:257-68.

36. Scalbert A, Manach C, Morand C, Remesy C. Dietary polyphenols and the prevention of diseases. Crit Rev Food Sci Nutr. 2005:45:287-306.

37. López MD, Pascual-Villalobos MJ. Mode of inhibition of acetylcholinesterase by monoterpenoids and implications for pest control. Ind Crop Prod. 2010; 31:284-8.

38. Mukherjee PK, Kumar V, Mal M, Houghton PJ. Acetylcholinesterase inhibitors from plants. Phytomedicine. 2007;14:289-300.

39. Gauthier S, Emre M, Farlow MR, Bullock R, Grossberg GT, Potkin SG. Strategies for continued successful treatment of Alzheimer's disease: switching cholinesterase inhibitors. Curr Med Res Opin. 2003:19(8):707-14.

40. Oboh G, Agunloye OM, Akinyemi AJ, Ademiluyi AO, Adefegha SA. Comparative study on the inhibitory effect of caffeic and chlorogenic acids on key enzymes linked to Alzheimer's disease and some pro-oxidant 
induced oxidative stress in rats' brain-in vitro. Neurochem Res. 2013;38(2): 413-9.

41. White E, Shannon JS, Patterson RE. Relationship between vitamin and calcium supplement use and colon cancer. Cancer Epidemiol Biomark Prev. 1997;6:769-74

42. Mesaik MA, Zaheer UI H, Murad S. Biological and molecular docking studies on coagulin-H: human IL-2 novel natural inhibitor. Mol Immunol. 2006;3(11): 1855-163.

Submit your next manuscript to BioMed Central and we will help you at every step:

- We accept pre-submission inquiries

- Our selector tool helps you to find the most relevant journal

- We provide round the clock customer support

- Convenient online submission

- Thorough peer review

- Inclusion in PubMed and all major indexing services

- Maximum visibility for your research

Submit your manuscript at www.biomedcentral.com/submit 